\title{
Persistent/Recurrent Syringomyelia after Chiari Decompression-Natural History and Management Strategies: A Systematic Review
}

\author{
James M. Schuster ${ }^{1} \quad$ Fangyi Zhang ${ }^{2,3}$ Daniel C. Norvell ${ }^{4}$ Jeffrey T. Hermsmeyer ${ }^{4}$
}

${ }^{1}$ Department of Neurological Surgery, Hospital of the University of

Address for correspondence James M. Schuster, MD, Hospital of the Pennsylvania, Philadelphia, Pennsylvania, United States

2 Department of Orthopedics and Sports Medicine, University of Washington, Harborview Medical Center, Seattle, Washington, United States

${ }^{3}$ Department of Neurological Surgery, University of Washington,

Harborview Medical Center, Seattle, Washington, United States

${ }^{4}$ Spectrum Research, Inc., Tacoma, Washington, United States University of Pennsylvania, 3 Silverstein, 3400 Spruce Street, Philadelphia, PA 19104, United States (e-mail: james.schuster@uphs.upenn.edu).

Evid Based Spine Care J 2013;4:116-125.

\begin{abstract}
Study Design Systematic review.

Study Rationale One of the most consistent indications for a Chiari decompression is tonsillar descent meeting the radiographic criteria and an associated syrinx in a symptomatic patient. In counseling patients about surgery, it would be advantageous to have information regarding the expected outcome with regard to the syrinx and other possible treatments available if the result is suboptimal.

Clinical Questions The clinical questions include: (1) What is the average rate of recurrent or residual syringomyelia following posterior fossa decompression as a result of Chiari malformation with associated syringomyelia? (2) What treatment methods have been reported in the literature for managing recurrent or residual syringomyelia after initial posterior fossa decompression?

Materials and Methods Available search engines were utilized to identify publications dealing with recurrent or residual syrinx after Chiari decompression and/or management of the syrinx. Rates of residual or recurrent syrinx were extracted and management strategies were recorded. Overall strength of evidence was quantified.

Results Of the 72 citations, 11 citations met inclusion criteria. Rates of recurrent/ residual syringomyelia after decompression in adults range from 0 to $22 \%$ with an average of $6.7 \%$. There were no studies that discussed specifically management of the remaining syrinx.

Conclusion Rates of recurrent/residual syringomyelia after Chiari decompression in adults range from 0 to $22 \%$ (average $6.7 \%$ ). Although no studies describing the optimal management of residual syrinx were found, there is general agreement that the aim of

Keywords

- Chiari decompression

- residual syrinx the initial surgery is to restore relatively unimpeded flow of cerebrospinal across the craniocervical junction. Large holocord syrinx may induce a component of spinal cord injury even with adequate decompression and reduction in the caliber of the syrinx, resulting in permanent symptoms of injury.
\end{abstract}

received

June 24, 2013

accepted after revision

July 30, 2013 (c) 2013 Georg Thieme Verlag KG

Stuttgart · New York
DOI http://dx.doi.org/ 10.1055/s-0033-1357362. ISSN 1663-7976. 


\section{Study Rationale and Context}

Syringomyelia is a cystic cavitation of the spinal cord containing fluid that is identical or similar to cerebrospinal (CSF) and is associated with a variety of pathophysiological conditions.

There is a dearth of studies in the literature on the treatment of syringomyelia as a result of meningitis, tumor, arachnoiditis, or hemorrhage. Bonfield et al $^{1}$ performed a systematic review on traumatic syringomyelia. They concluded there is no indication for direct decompression at the time of injury, specifically, for the purpose of limiting future risk of syringomyelia, and that the literature does not provide strong evidence to support the superiority of one surgical technique over others. As a systematic review has already been done on traumatic syringomyelia, we chose to search for a population with associated syringomyelia as a result of acquired ArnoldChiari malformation in adults. Approximately 50 to $70 \%$ of patients with Chiari I malformation, as defined by tonsillar ectopia located below the foramen magnum, have associated syringomyelia. Symptoms are often present between the ages of 20 and 50 years, and it is slightly more prevalent in females than in males. Surgical treatment options include any combination of the following: suboccipital craniectomy with $\mathrm{C} 1$ laminectomy (can be a purely extradural approach), with or without duraplasty (utilizing dural substitutes or the patient's own tissue, including pericranium or fascia lata), with or without intradural lysis of arachnoid adhesions, with or without shrinkage/resection of cerebellar tonsils, with or without expansive cranioplasty. There are no studies in the literature comparing treatments for this condition; however, there are case series reporting surgical outcomes. Our interest was in summarizing the rates of recurrent or residual syringomyelia after surgery in this population; therefore, we sought to summarize rates after the most common surgical procedure (posterior fossa decompression) for syringomyelia as a result of Chiari malformation in adults to provide surgeons and patients with information on prognosis after surgery. We also sought to summarize various methods described for treating residual/ recurrent syringomyelia.

Surgery for Chiari I malformation continues to be a controversial area when taken in its entirety. The radiographic definition and interpretation can be vague, the signs and symptoms attributed to the condition overlap with many other common conditions, and there are many different surgical techniques available. One of the most consistent indications for a Chiari decompression is tonsillar descent meeting the radiographic criteria and an associated syrinx in a symptomatic patient. As we know, the syrinx can be small and limited to the cervical region or on the other extreme, involving the entire cord and lower brainstem. These holocord syrinxes often present with myelopathy-type signs and symptoms and radiographically exhibit extensive cord distortion and signal change. After decompression, which in our practice involves craniectomy around the foramen magnum, C1 laminectomy, and dural augmentation with a pericranium graft, smaller syrinxes often disappear completely or reduce to a minimum. We counsel patients who are symptomatic from a holocord syrinx, that the syrinx may decrease in size but will not disappear completely. This generally gives the appearance of a long balloon preoperatively that appears to have had the air-released postoperatively. We also counsel patients that these larger syrinxes most likely produce spinal cord injury, and as in traumatic spinal cord injury, there is a high likelihood of having residual symptoms, even with significant decrease in the size of the syrinx.

The difficulty arises when there is only minimal or no change in the size of the syrinx postoperatively or if there is possible reexpansion sometime after the initial decompression. With regard to no change immediately after decompression, there is always the concern that the initial decompression was inadequate, perhaps from insufficient bone removal at the foramen magnum or $\mathrm{C}$. Some advocate bony removal with release of the dural band at the level of the foramen without opening the dura, which is more common in the pediatric population and has been associated with a need for reoperation in certain cases. There is also the proposal that arachnoid adhesions at the level of the tonsils and foramen of Monroe contribute to persistent alterations in CSF dynamics, arguing for intradural and arachnoid exploration. In cases that appear to have adequate decompression and the syrinx is only minimally changed in size, or in the case of possible reexpansion of the syrinx in which there was felt to be adequate decompression, there is the concern that the syrinx needs to be addressed directly. Again, in making these decisions, it is important to remember that especially in the case of a patient with a large syrinx and significant residual symptoms, attempts to further reduce the size of the syrinx may not lead to improved functional outcome and is associated with additional risks to the patient.

\section{Clinical Question}

1. What is the average rate of recurrent or residual syringomyelia following posterior fossa decompression as a result of Chiari malformation with associated syringomyelia?

2. What treatment methods have been reported in the literature for managing recurrent or residual syringomyelia after initial posterior fossa decompression?

\section{Materials and Methods}

Study design: Systematic review (see online supplementary material for expanded methods).

Search: The databases included PubMed, Cochrane, and National Guideline Clearinghouse Databases, as well as bibliographies of key articles.

Dates searched: The data were searched through April 15, 2013.

Inclusion criteria: Adult patients with Chiari malformation and associated syringomyelia who have undergone posterior fossa decompression were included in the study.

Exclusion criteria: Patients younger than 18 years, those sustaining trauma, meningitis, tumor, hemorrhage, arachnoiditis, and Chiari with no presence of syringomyelia, as well as those treated by any other treatment than posterior fossa decompression were excluded. Case reports, studies with 
fewer than 10 patients, nonhuman in vivo, in vitro, and biomechanical studies were also excluded.

Outcomes: Recurrent or residual syringomyelia; reported management/treatment of recurrent or residual syringomyelia.

Analysis: We reported the raw numbers and rates provided by each author for the primary outcome. When not reported by the authors, we calculated the rate by dividing the number of events by the total number of subjects in the study. The rates were transferred to a summary table and presented by individual study then combined to calculate an overall rate. There was no analysis for management strategies of this complication. These were described when reported by the author.

Overall strength of evidence: Risk of bias for individual prognostic studies was on the basis of using criteria set by The Journal of Bone and Joint Surgery ${ }^{2}$ modified to delineate criteria associated with methodological quality and risk of bias based on recommendation from the Agency for Healthcare Research and Quality (AHRQ). ${ }^{3,4}$ The overall strength of evidence across studies was on the basis of precepts outlined by the Grades of Recommendation Assessment, Development and Evaluation (GRADE) Working Group ${ }^{5}$ and recommendations made by the AHRQ. ${ }^{3,4}$

\section{Results}

- From a total of 72 citations retrieved, 20 citations were evaluated for full-text review, and $11^{6-16}$ met the inclusion criteria for this report (-Fig. 1).

- Nine studies were excluded at full text for the following reasons: other than posterior fossa decompression $(n=1)$; posterior fossa decompression with different secondary surgery techniques $(n=2) ; n<10(n=2)$; pediatric patients $(n=2)$; review study $(n=2)$.

- The 11 included studies described the following outcomes consistent with residual or recurrent syringomyelia: worsening of condition $(n=7)^{6,8,11-14,16}$; increase syrinx size $(n=3)^{9,10,15}$; residual or recurrent syringomyelia $(n=1)^{7}$ (-Table 1).

- When considering all three outcomes together as a single complication, the rates ranged from $0^{8,10,13,14}$ to $22.2 \%{ }^{11}$ (-Table 2). The combined rate across studies was 6.7\% (-Table 2). When reporting these outcomes separately, the combined rates for worsening, recurrent/residual, and increase in syrinx size were $10.2,0.6$, and $1.8 \%$, respectively.

- None of the 11 studies reported on the management of these complications.

- All the 11 studies ${ }^{6-16}$ had patients at similar points in their course of disease or treatment and patients were also followed long enough for outcomes to occur. Only three studies $^{6,8,11}$ report a follow-up rate, which ultimately effects the overall level of evidence for each individual study. In no study did the authors evaluate risk factors for the outcome.

\section{Evidence Summary}

- Rates of recurrent/residual syringomyelia after posterior fossa decompression in adults range from 0 to $22 \%$ with an average across studies of $6.7 \%$. These studies are case series from different populations. Because of the low quality of individual studies and the inconsistency between studies, there is insufficient evidence to establish

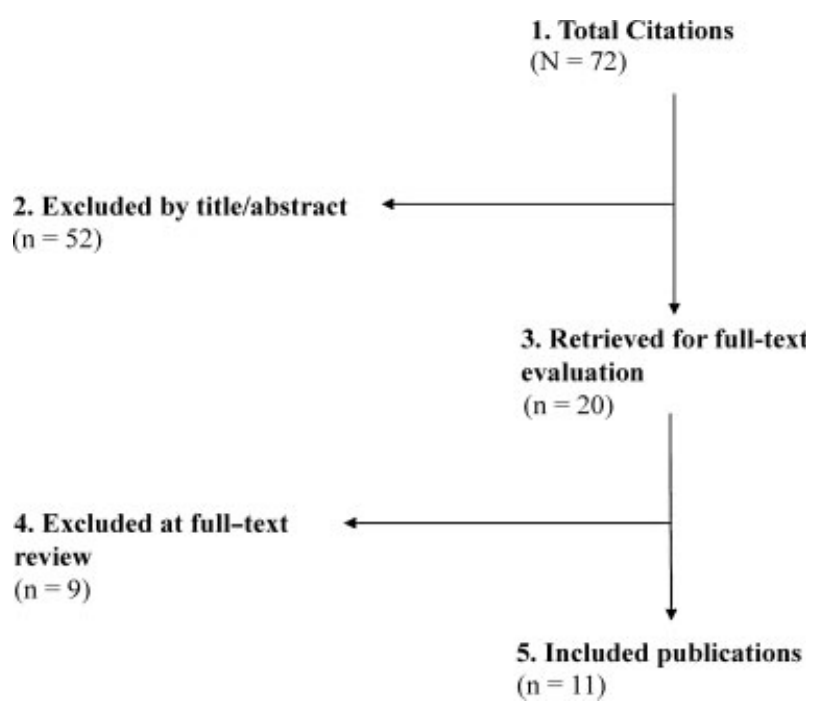

Fig. 1 Flowchart showing results of literature search. 
Persistent/Recurrent Syringomyelia after Chiari Decompression Schuster et al. 119

Table 1 Characteristics of included studies with patients having Chiari malformation with syringomyelia treated by posterior decompression

\begin{tabular}{|c|c|c|c|c|c|}
\hline Author (y) & Study design & Study population & $\begin{array}{l}\text { Initial } \\
\text { decompression }\end{array}$ & $\begin{array}{l}\text { Rate of recurrent or } \\
\text { residual } \\
\text { syringomyelia }\end{array}$ & Treatment \\
\hline $\begin{array}{l}\text { Zhang et al } \\
\text { (2011) }\end{array}$ & Case-series & $\begin{array}{l}N=132 \text { Chiari mal- } \\
\text { formation with associ- } \\
\text { ated syringomyelia } \\
\text { Mean age: } 33 \pm 13 \text { y } \\
\text { (age range, } 14-62 \text { y) } \\
\text { Sex: } 43.9 \% \text { male } \\
\text { Mean F/U: } 2.3 \text { y } \\
\text { (range, } 6 \text { mo-11 y) }\end{array}$ & $\begin{array}{l}\text { PFD } \\
\text { - Extended PFD } \\
\text { (large craniotomy } \\
\text { group) } n=69 \\
\text { - Local PFD (small } \\
\text { craniotomy } \\
\text { group) } n=63\end{array}$ & $\begin{array}{l}\text { Syringomyelia changes } \\
\text { in extended and local } \\
\text { PFD: } \\
\text { Extended PFD: } \\
\text { • Improvement } \\
51 / 69(74 \%) \\
\text { - Worse } 5 / 69(7.2 \%) \\
\text { Local PFD: } \\
\text { - Improvement } \\
57 / 63(90 \%) \\
\text { - Worse } 0 / 63(0 \%)\end{array}$ & NR \\
\hline $\begin{array}{l}\text { Alfieri and Pinna } \\
(2012)\end{array}$ & Case-series & $\begin{array}{l}N=109 \text { Chiari mal- } \\
\text { formation with associ- } \\
\text { ated syringomyelia } \\
\text { Mean age: } \\
46 \pm 13.7 \text { y (age } \\
\text { range, } 18-77 \text { y) } \\
\text { Sex: } 41.2 \% \text { male } \\
\text { Mean F/U: } 12.7 \text { y } \\
\text { (range, } 9-15 \mathrm{y} \text { ) } \\
\text { F/U rate: } 109 / 111 \\
\text { (98.2\%); two patients } \\
\text { lost to F/U }\end{array}$ & PFD & $\begin{array}{l}\text { 1-year F/U: } \\
\text { • Improvement } \\
\text { 32/109 (29.4\%) } \\
\text { - No change 62/109 } \\
\text { (56.9\%) } \\
\text { - Worse 15/69 } \\
\text { (13.7\%) } \\
\text { Last F/U: } \\
\text { • Improvement } \\
\text { 32/109 (29.4\%) } \\
\text { - No change 60/109 } \\
\text { (55\%) } \\
\text { - Worse 17/69 } \\
\text { (15.6\%) }\end{array}$ & NR \\
\hline $\begin{array}{l}\text { Batzdorf et al } \\
\text { (2013) }\end{array}$ & Case-series & $\begin{array}{l}N=177 \text { Chiari mal- } \\
\text { formation with } n=97 \\
\text { having associated sy- } \\
\text { ringomyelia } \\
\text { Mean age: } 37.9 \text { y (age } \\
\text { range, } 15-78 \text { y) } \\
\text { Sex: } 25.4 \% \text { male } \\
\text { Mean F/U: } 88.5 \text { wk } \\
\text { (range, } 8-623 \text { wk) }\end{array}$ & $\begin{array}{l}\text { Posterior fossa } \\
\text { decompression (PFD) }\end{array}$ & $\begin{array}{l}\text { Recurrent syringomye- } \\
\text { lia: } 1 / 177(0.6 \%) \\
\text { Patients requiring reop- } \\
\text { eration: } 1 / 177(0.6 \%)\end{array}$ & NR \\
\hline $\begin{array}{l}\text { Depreitere et al } \\
(2000)\end{array}$ & Case-series & $\begin{array}{l}N=22 \text { Chiari malfor- } \\
\text { mation with associat- } \\
\text { ed syringomyelia } \\
\text { Mean age: } 39 \text { y (age } \\
\text { range, } 5-70 \text { y) } \\
\text { Sex: } 54.5 \% \text { male } \\
\text { Mean F/U: } 18 \text { mo } \\
\text { (range, } 4-42 \text { mo) } \\
\text { F/U rate: } 19 / 23 \\
\text { ( } 82.6 \% \text { ); one patient } \\
\text { lost to F/U and data } \\
\text { available on } 19 \text { of } 22 \\
\text { patients }\end{array}$ & PFD & $\begin{array}{l}\text { - } \text { No improvement } \\
\text { (no collapse) } \\
1 / 22(4.5 \%) \\
\text { - Some } \\
\text { improvement } \\
\text { (segmental } \\
\text { collapse) } 11 / 22 \\
\text { (50\%) } \\
\text { - Total improvement } \\
\text { (total collapse) 8/22 } \\
\text { (36.3\%) } \\
\text { - Unknown 2/22 (9\%) } \\
\text { - Worsening 0/22(0\%) }\end{array}$ & NR \\
\hline $\begin{array}{l}\text { Ellenbogen et al } \\
(2000)\end{array}$ & Case-series & $\begin{array}{l}N=29 \text { Chiari malfor- } \\
\text { mation with } n=22 \\
\text { having associated } \\
\text { syringomyelia } \\
\text { Mean age: } 34.5 \text { y } \\
\text { Sex: } 44.8 \% \text { male } \\
\text { Mean F/U: } 4.1 \text { y }\end{array}$ & PFD & $\begin{array}{l}\text { - Good (collapse } \\
>75 \% \text {, returned to } \\
\text { normal lifestyle with } \\
\text { no restrictions) } \\
20 / 29 \text { (69\%) } \\
\text { - Improved (collapse } \\
>75 \%, \text { returned to } \\
\text { normal lifestyle with } \\
\text { some restrictions) } \\
8 / 29(28 \%) \\
\text { - Poor (residual syrinx) } \\
1 / 29(3 \%)\end{array}$ & NR \\
\hline
\end{tabular}


Table 1 (Continued)

\begin{tabular}{|c|c|c|c|c|c|}
\hline Author (y) & Study design & Study population & $\begin{array}{l}\text { Initial } \\
\text { decompression }\end{array}$ & $\begin{array}{l}\text { Rate of recurrent or } \\
\text { residual } \\
\text { syringomyelia }\end{array}$ & Treatment \\
\hline Fischer (1995) & Case-series & $\begin{array}{l}N=12 \text { Chiari malfor- } \\
\text { mation with associat- } \\
\text { ed syringomyelia } \\
\text { Mean age: } 48.3 \text { y (age } \\
\text { range, } 24-67 \text { y) } \\
\text { Sex: NR } \\
\text { Mean F/U: NR }\end{array}$ & PFD & $\begin{array}{l}\text { Syrinx size: } \\
\text { • Gone } 2 / 12(16.7 \%) \\
\text { - Slit-like } 4 / 12 \\
\quad(33.4 \%) \\
\text { - } 75 \% \text { smaller } 3 / 12 \\
\quad(25 \%) \\
\text { - } 50 \% \text { smaller } 2 / 12 \\
\quad(16.7 \%) \\
\text { - Some decrease } 1 / 12 \\
\quad(8.3 \%)\end{array}$ & NR \\
\hline $\begin{array}{l}\text { Garcia-Uria } \\
(1981)\end{array}$ & Case-series & $\begin{array}{l}N=31 \text { Chiari malfor- } \\
\text { mation with associat- } \\
\text { ed syringomyelia } \\
\text { Mean age: NR } \\
\text { Sex: } 51.6 \% \text { male } \\
\text { Mean F/U: NR,(age } \\
\text { range, } 5-10 \text { y) } \\
\text { F/U rate: } 27 / 31(87 \%)\end{array}$ & PFD & $\begin{array}{l}\text { - Improvement 15/27 } \\
\text { (55.5\%) } \\
\text { - No change 6/27 } \\
\text { (22.2\%) } \\
\text { - Deterioration 6/27 } \\
\text { (22.2\%) }\end{array}$ & NR \\
\hline $\begin{array}{l}\text { Mueller and Oro' } \\
(2005)\end{array}$ & Case-series & $\begin{array}{l}N=112 \text { Chiari mal- } \\
\text { formation with associ- } \\
\text { ated syringomyelia } \\
\text { Mean age: } \\
40 \pm 11.3 \text { y (age } \\
\text { range, } 17-70 \text { y) } \\
\text { Sex: } 7.1 \% \text { male } \\
\text { Mean F/U: NR }\end{array}$ & PFD & $\begin{array}{l}\text { QOL reported: } \\
\text { - Improvement } \\
\text { 84/112 (75\%) } \\
\text { - No change } 17 / 112 \\
\text { (15.2\%) } \\
\text { - Deterioration } \\
11 / 112(9.8 \%)\end{array}$ & NR \\
\hline $\begin{array}{l}\text { Noudel et al } \\
(2011)\end{array}$ & Case-series & $\begin{array}{l}N=11 \text { Chiari malfor- } \\
\text { mation with associat- } \\
\text { ed syringomyelia } \\
\text { Mean age: } 35 \text { y (age } \\
\text { range, } 15-67 \text { y) } \\
\text { Sex: } 54.5 \% \text { male } \\
\text { Mean F/U: NR }\end{array}$ & PFD & $\begin{array}{l}\text { Improved recovery } \\
11 / 11 \\
\text { - Complete recovery } \\
4 / 11(36.3 \%) \\
\text { - Partial recovery } \\
\text { 7/11 (63.6\%) }\end{array}$ & NR \\
\hline Silva et al (2010) & Case-series & $\begin{array}{l}N=10 \text { Chiari malfor- } \\
\text { mation with associat- } \\
\text { ed syringomyelia } \\
\text { Mean age: } 35.4 \text { y (age } \\
\text { range, } 26-59 \text { y) } \\
\text { Sex: } 50 \% \text { male } \\
\text { Mean F/U: } 2.8 \text { y }\end{array}$ & PFD & $\begin{array}{l}\text { - Improvement 10/10 } \\
\text { (100\%) } \\
\text { - Worsening 0/10 } \\
(0 \%)\end{array}$ & NR \\
\hline $\begin{array}{l}\text { Vaquero et al } \\
(1990)\end{array}$ & Case-series & $\begin{array}{l}N=15 \text { Chiari malfor- } \\
\text { mation with associat- } \\
\text { ed syringomyelia } \\
\text { Mean age: NR } \\
\text { Sex: NR } \\
\text { F/U at least } 1 \text { y after } \\
\text { surgery }\end{array}$ & PFD & $\begin{array}{l}\text { Syrinx size: } \\
\text { - Decrease in syrinx } \\
\text { diameter } 14 / 15 \\
(93.3 \%) \\
\text { - No change in syrinx } \\
\text { diameter } \\
1 / 15(6.7 \%) \\
\text { Subjective outcome: } \\
\text { - Improvement } 7 / 15 \\
\text { (46.6\%) } \\
\text { - No change 4/15 } \\
\text { (26.6\%) } \\
\text { - Worse 4/15 (26.6\%) }\end{array}$ & NR \\
\hline
\end{tabular}

Abbreviations: F/U, follow-up; NR, not reported; PFD, posterior fossa decompression; QOL, quality of life. 
Table 2 Outcomes after PFD for Chiari malformation with associated syringomyelia

\begin{tabular}{|l|l|l|l|c|}
\hline \multirow{2}{*}{ Author (y) } & Worsening & Recurrent/residual & Increase of syrinx size & Total \\
\cline { 2 - 5 } & $n / N(\%)$ & $n / N(\%)$ & $n / N(\%)$ & $5 / 132(3.8)$ \\
\hline Zhang et al (2011) & $5 / 132(3.8)$ & & & $17 / 69(15.6)$ \\
\hline Alfieri and Pinna (2012) & $17 / 69(15.6)$ & & & $1 / 177(0.6)$ \\
\hline Batzdorf et al (2013) & & $1 / 177(0.6)$ & & $0 / 22(0)$ \\
\hline Depreitere et al (2000) & $0 / 22(0)$ & & $1 / 29(3.4)$ & $1 / 29(3.4)$ \\
\hline Ellenbogen et al (2000) & & & $0 / 12(0)$ & $0 / 12(0)$ \\
\hline Fischer (1995) & & & & $6 / 27(22.2)$ \\
\hline Garcia-Uria (1981) & $6 / 27(22.2)$ & & & $11 / 112(9.8)$ \\
\hline Mueller and Oro' (2005) & $11 / 112(9.8)$ & & & $0 / 11(0)$ \\
\hline Noudel et al (2011) & $0 / 11(0)$ & & & $0 / 10(0)$ \\
\hline Silva et al (2010) & $0 / 10(0)$ & & & $0 / 15(0)$ \\
\hline Vaquero et al (1990) & & & & $41 / 616(6.7)$ \\
\hline Combined & $39 / 383(10.2)$ & $1 / 177(0.6)$ & & \\
\hline
\end{tabular}

Abbreviation: PFD, posterior fossa decompression.

an expected rate of recurrence; however, we can provide surgeons and patients with a range of estimates to consider (-Table $\mathbf{3}$ ).

\section{Illustrative Case}

The patient is a 30 -year-old woman with a several-year history of worsening neck pain with bilateral burning dysesthesias and numbness in her upper extremities, worse on the right side. She underwent a Chiari decompression at an outside institution complicated by persistent pseudomeningocele requiring a ventriculoperitoneal shunt. The patient had persistent symptoms and reimaging was suggestive of persistent compression at the foramen magnum and $\mathrm{C} 1$ and persistent syrinx (-Figs. 2 and 3). She underwent re-exploration with increased bone removal at the foramen magnum and $\mathrm{C} 1$ with dural expansion using pericranium. At the time of surgery, CSF flow was noted from between and around the tonsils. Reimaging showed improved decompression (-Figs. 4 and 5). The patient initially had improvement in her symptoms but within a year had recurrent symptoms and evidence of recurrent/persistent syrinx (-Fig. 6). The patient underwent a syringopleural shunt with decreased caliber of the syrinx (-Fig. 7). The patient experienced improvement overall in her symptoms but continued to have chronic pain in her extremities.

Table 3 Evidence summary

\begin{tabular}{|l|l|l|}
\hline Outcomes & \multicolumn{1}{|l|}{$\begin{array}{l}\text { Strength of } \\
\text { evidence }\end{array}$} & Conclusions/comments \\
\hline $\begin{array}{l}\text { Question 1: What is the average rate of recurrent or residual syringomyelia following posterior fossa decompression as a result of } \\
\text { Chiari malformation with associated syringomyelia? }\end{array}$ & $\begin{array}{l}\text { Rates of recurrent/residual syringomyelia after pos- } \\
\text { terior fossa decompression in adults range from } \\
0-22 \% \text { with an average across studies of 6.7\%. These } \\
\text { studies are case series from different populations. } \\
\text { Because of the low quality of individual studies and } \\
\text { the inconsistency between studies, there is insuffi- } \\
\text { residual } \\
\text { syringomyelia } \\
\text { cient evidence to establish an expected rate of re- } \\
\text { currence; however, we can provide surgeons and } \\
\text { patients with a range of estimates to consider. }\end{array}$ \\
\hline $\begin{array}{l}\text { Question 2: What treatment methods have been reported in the literature for managing recurrent or residual syringomyelia after } \\
\text { initial posterior fossa decompression? }\end{array}$ & $\begin{array}{l}\text { Insufficient } \\
\text { Treatments }\end{array}$ Not applicable & $\begin{array}{l}\text { This was a descriptive key question and therefore an } \\
\text { overall strength of evidence is not applicable. }\end{array}$ \\
\hline
\end{tabular}




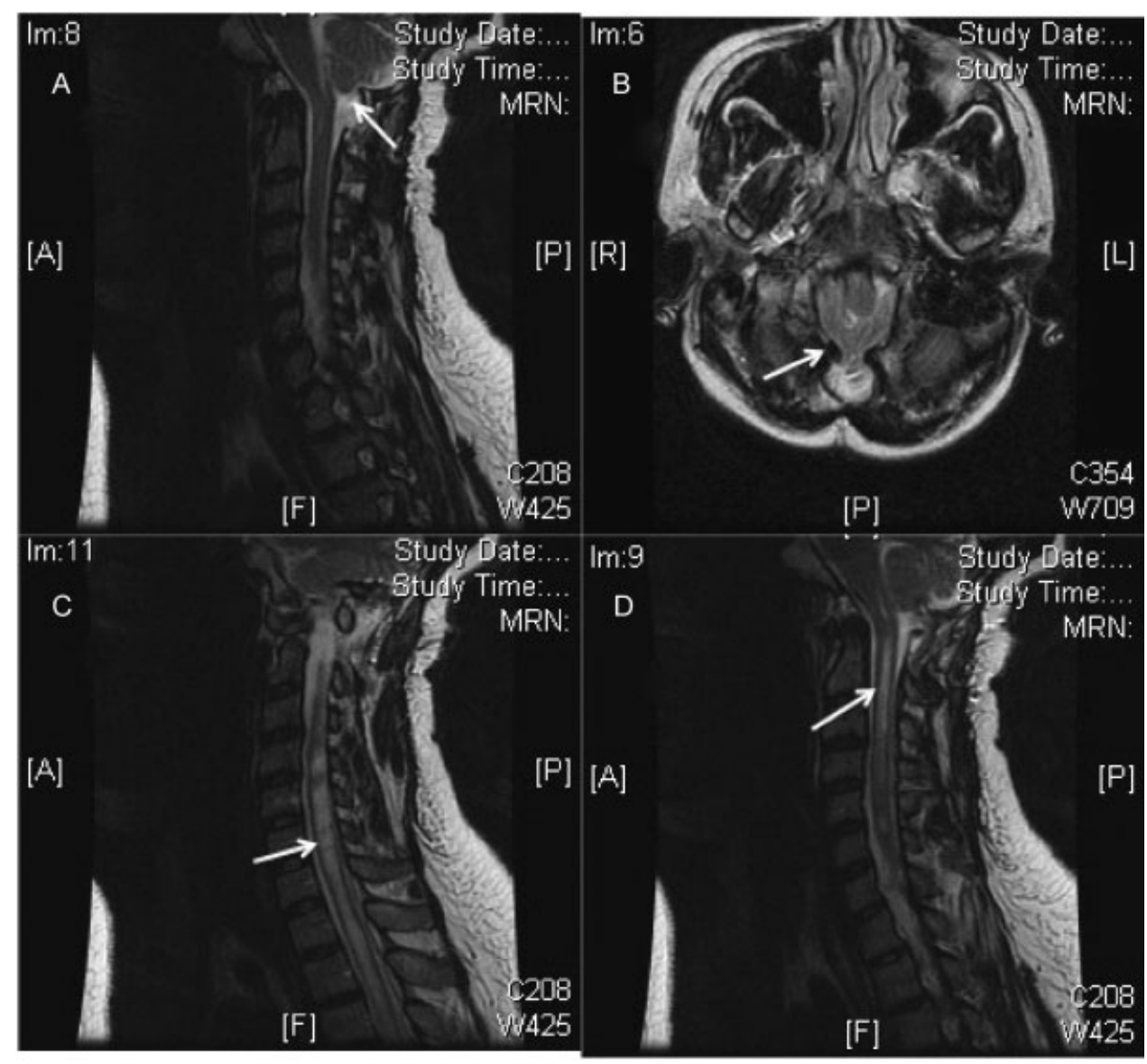

Fig. 2 Persistent compression after Chiari procedure (A, B) with persistent syrinx (B, C).

\section{Discussion}

- Rates of recurrent/residual syringomyelia after posterior fossa decompression in adults range from 0 to $22 \%$ with an average across studies of $6.7 \%$. These studies are case series from different populations.
- Although there are no studies describing the most appropriate method of managing recurrent/residual syringomyelia after posterior fossa decompression in adult patients, there is general agreement today that the aim of initial decompression surgery is to restore relatively unimpeded flow of CSF across the craniocervical junction, so that the

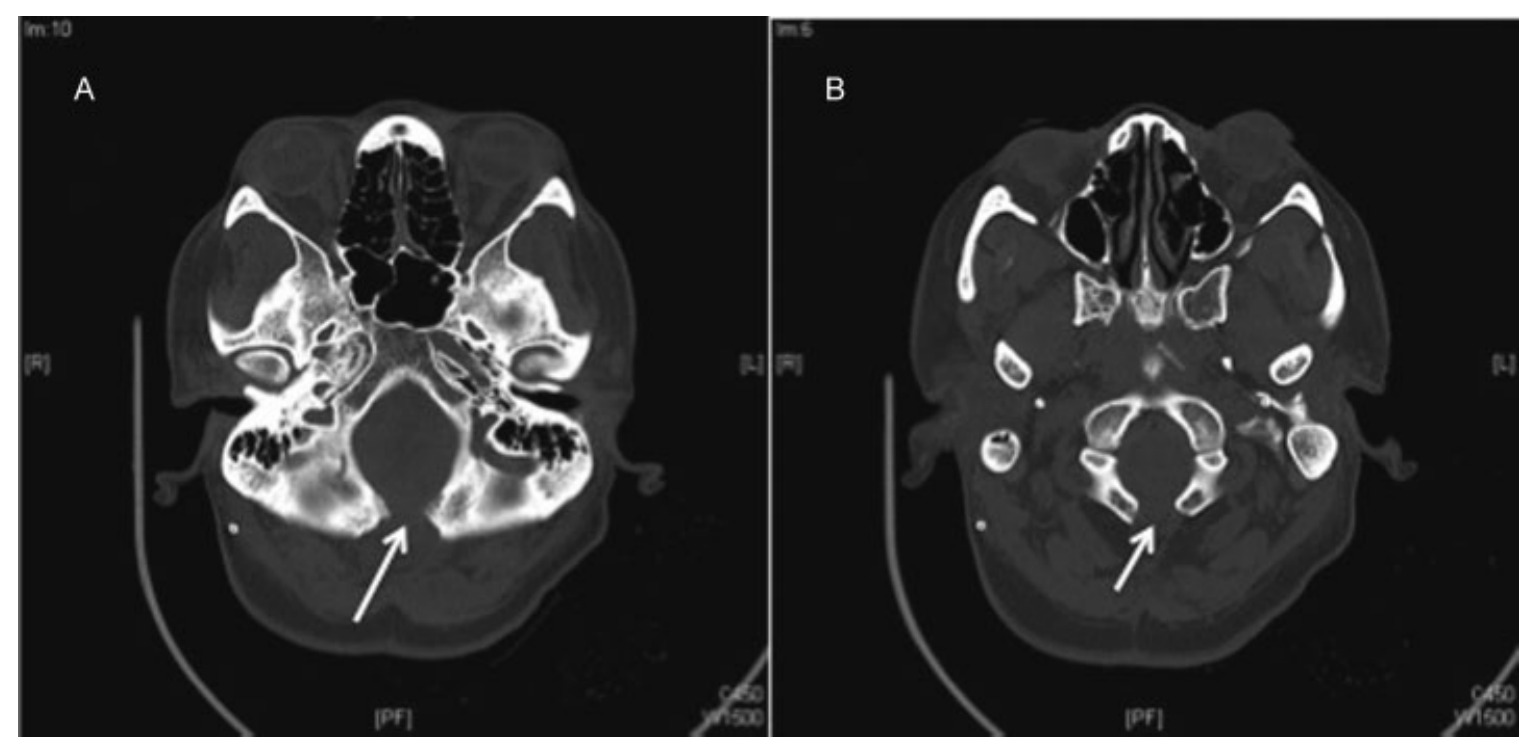

Fig. 3 Computed tomography showing persistent compression at the foramen magnum (A) and C1 (B). 

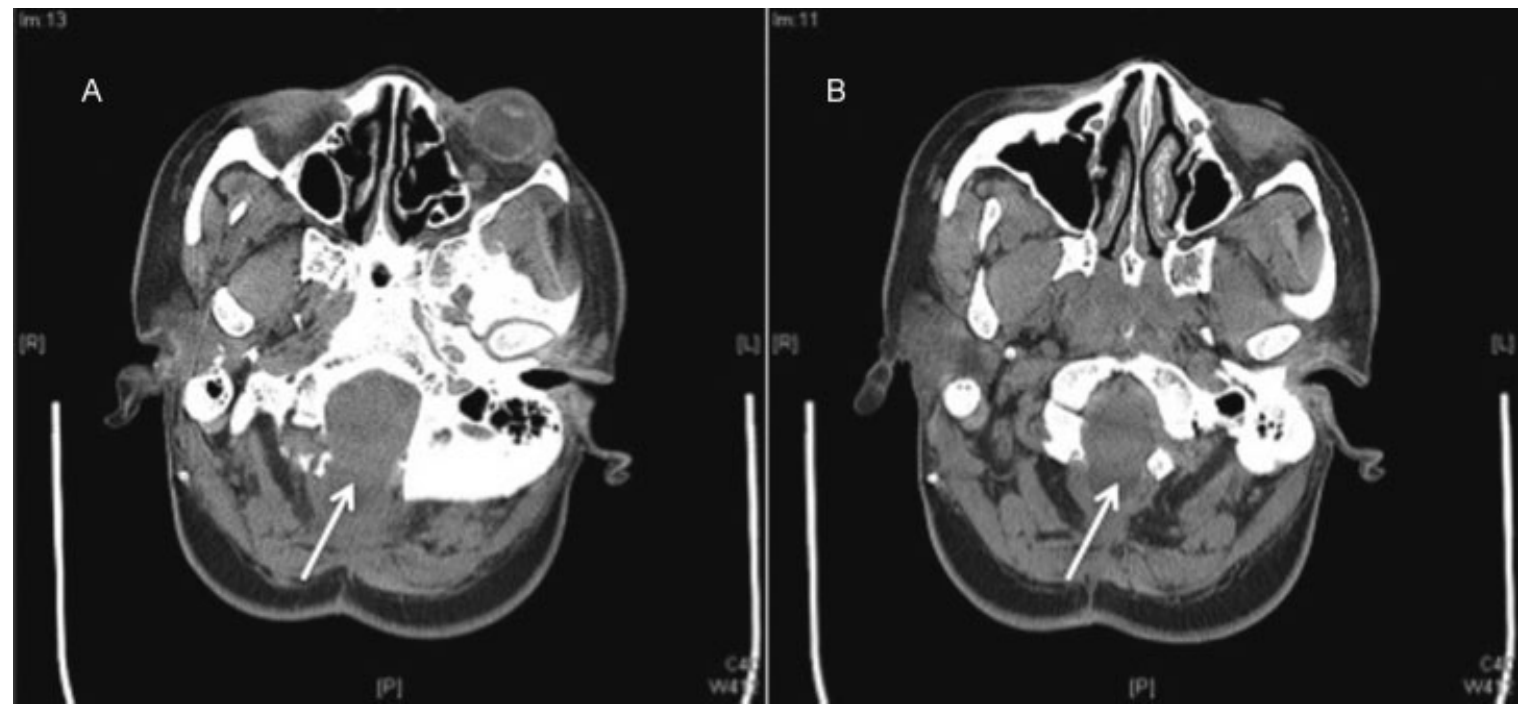

Fig. 4 Increased bone removal after revision decompression.

normal CSF pulsations, coincident with the arterial pulse and respiration, are transmitted into the spinal subarachnoid space.

- It has been proposed that the surgical procedures that enlarge the subtonsillar and retrotonsillar CSF cisterns correlate with good clinical outcomes. Indeed, the latest evidence demonstrates that expansion of these basal cisterns correlates the reduction in size of the syringomyelic cavity, a predictor of improvement in clinical symptoms and signs related to syringomyelia. ${ }^{7}$ Many approaches have been advocated including: extradural approaches only, (suboccipital craniectomy and C1 laminectomy), craniectomy/laminectomy/dural augmentation with or without lysis of arachnoid adhesions and possibly "shrinking" of the tonsils, and expansive cranioplasty. There is no standard for what would be considered "adequate" bone removal, but in general, enough bone must be removed laterally at the foramen magnum and at the $\mathrm{C}-1$ level to fully decompress the posterior aspect of the cerebellar tonsils. ${ }^{17}$ There are also many options for dural substitutes including autologous pericranium. There are no superiority studies but pericranium is nonimmunogenic, inexpensive, and capable of creating a watertight closure with the dura. ${ }^{18}$

- With a persistent syrinx after initial decompression, the possibility exists that an obstruction of CSF pathways at the foramen magnum was not relieved with the original procedure. Before considering re-exploration, other causes of failure, including basilar invagination, instability, hypermobility at the craniocervical junction, prominent $(>9 \mathrm{~mm}$ ) retroflexion of the dens, or the possibility of a tethered cord, should be eliminated if not eliminated before the original
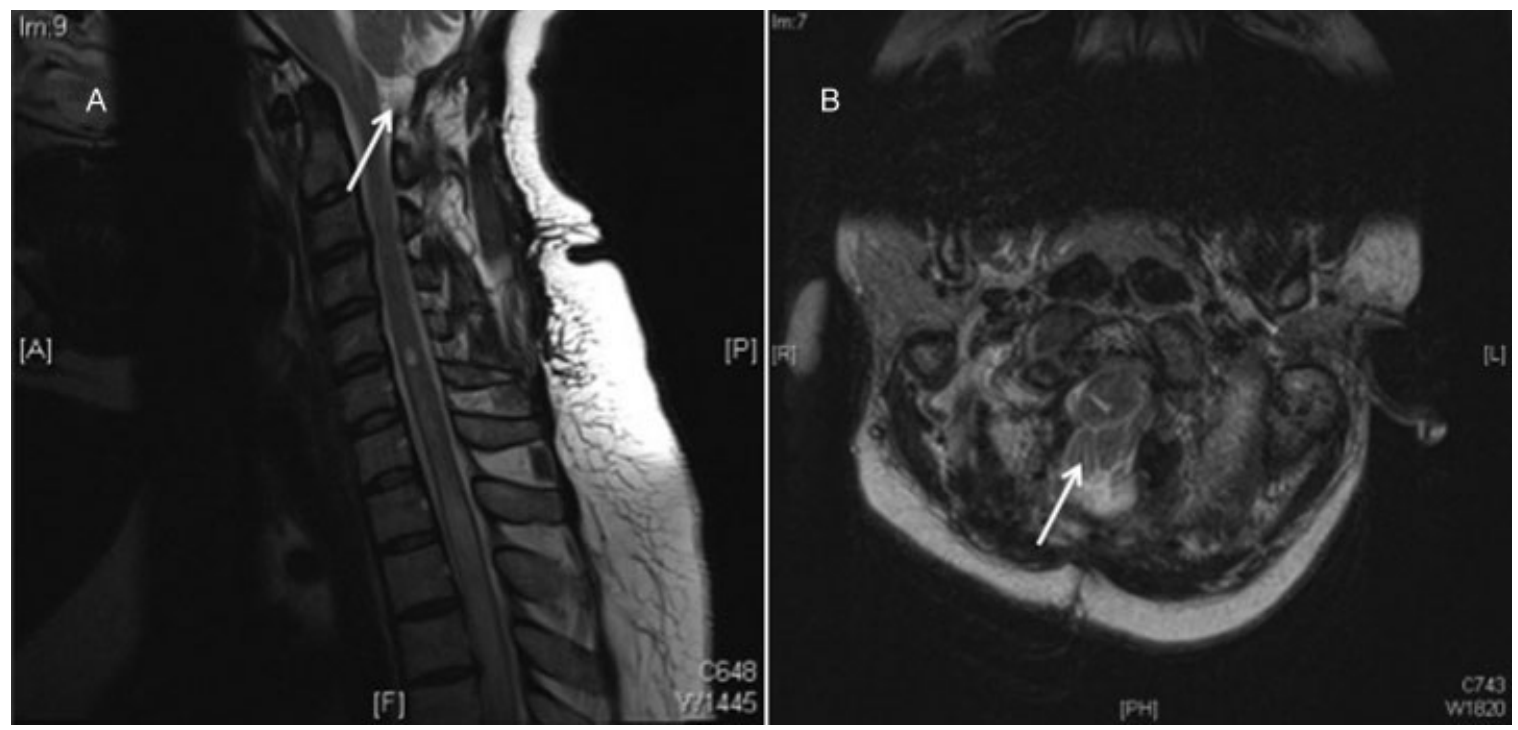

Fig. 5 Improved decompression at the skull base. 


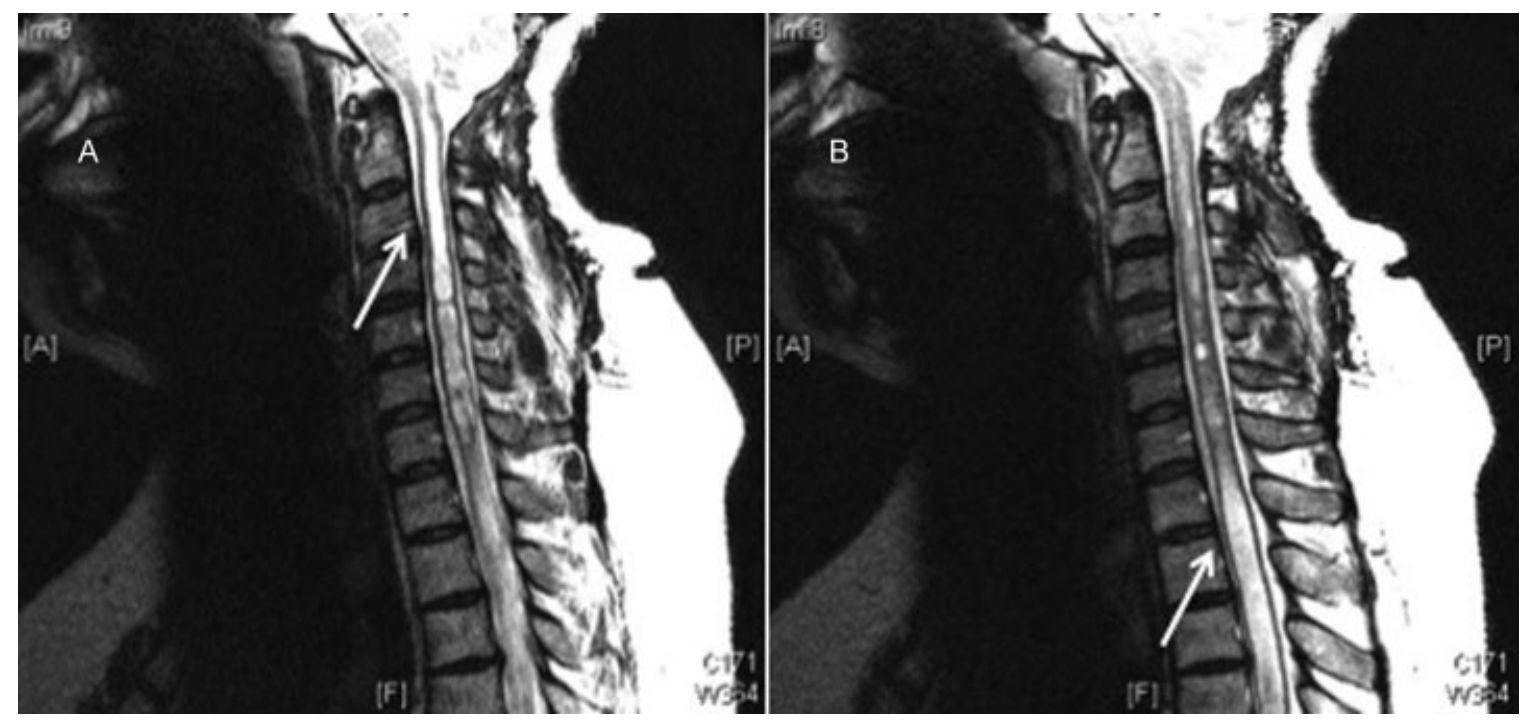

Fig. 6 Persistent/recurrent syrinx.
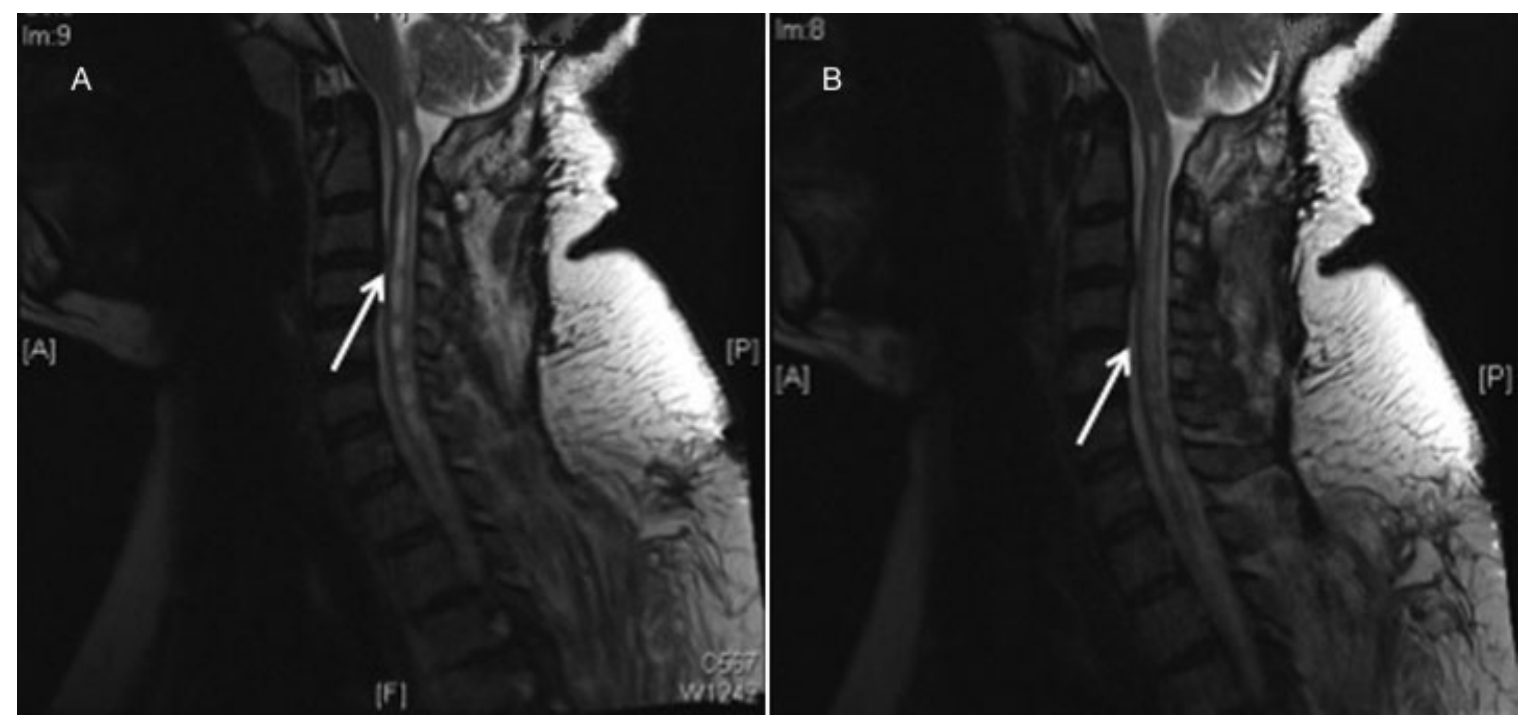

Fig. 7 Decrease caliber of syrinx after syringopleural shunt.

procedure. Preoperative evaluations with magnetic resonance imaging (MRI) and cine MRI can help determine the adequacy of the CSF space at the foramen magnum. Intraoperative ultrasound at the time of surgery (either initial or revision) can be used to document adequate decompression by showing that the tonsils no longer pathologically descend with cardiac systole. ${ }^{17}$

- Large holocord syrinx most likely induces a component of spinal cord injury even with adequate decompression and reduction in the caliber of the syrinx and may result in permanent symptoms of injury. This must be taken into account when counseling patients about the utility of addressing the syrinx directly (i.e., with a syringopleural shunt or syringo-subarachnoid shunt) after what appears to be adequate decompression. There have not been direct comparisons of re-decompression to shunting the syrinx, but because of the relatively short functional half-life of these shunts ( 4 years) in a relatively young patient population, reoperation may be a better option. ${ }^{17}$ With regard to the optimal shunting procedure, syringo-subarachnoid versus syringopleural or peritoneal, the syringopleural/ peritoneal shunts are more involved technically with a higher rate of complication but the syringo-subarachnoid shunts rely on free flow of CSF in the subarachnoid space, which may not be adequate secondary to adhesions leading to failure. ${ }^{19}$ Both procedures put the patient at increased risk of neurologic decline because of the need for myelotomy and catheter insertion in the cord.

- Future research should compare surgical approaches to the management of recurrent or residual syringomyelia after initial decompression in the same patient population.

- Observational studies should suffice as long as groups are similar with respect to factors that influence complications and other patient-centered outcomes. 
Disclosures
None

\section{Acknowledgments}

Analytic support for this work was provided by Spectrum Research, Inc. with funding from AOSpine.

\section{References}

1 Bonfield CM, Levi AD, Arnold PM, Okonkwo DO. Surgical management of post-traumatic syringomyelia. Spine (Phila Pa 1976) 2010; 35(21, Suppl):S245-S258

2 Wright JG, Swiontkowski MF, Heckman JD. Introducing levels of evidence to the journal. J Bone Joint Surg Am 2003;85-A(1):1-3

3 Methods Guide for Effectiveness and Comparative Effectiveness Reviews. AHRQ Publication No. 10(12)-EHC063-EF. Rockville, MD: Agency for Healthcare Research and Quality; April 2012. Available at: www.effectivehealthcare.ahrq.gov

4 West S, King V, Carey TS, et al. Systems to Rate the Strength of Scientific Evidence. Evidence Report/Technology Assessment No. 47 (Prepared by the Research Triangle Institute-University of North Carolina Evidence-based Practice Center, Contract No. 290-97-0011). Rockville, MD: Agency for Healthcare Research and Quality; 2002

5 Atkins D, Best D, Briss PA, et al; GRADE Working Group. Grading quality of evidence and strength of recommendations. BMJ 2004; 328(7454): 1490

6 Alfieri A, Pinna G. Long-term results after posterior fossa decompression in syringomyelia with adult Chiari Type I malformation. J Neurosurg Spine 2012;17(5):381-387

7 Batzdorf U, McArthur DL, Bentson JR. Surgical treatment of Chiari malformation with and without syringomyelia: experience with 177 adult patients. J Neurosurg 2013;118(2):232-242

8 Depreitere B, Van Calenbergh F, van Loon J, Goffin J, Plets C. Posterior fossa decompression in syringomyelia associated with a Chiari malformation: a retrospective analysis of 22 patients. Clin Neurol Neurosurg 2000;102(2):91-96

\section{Editorial Perspective}

EBSJ thanks the authors and the reviewers for their insights. In discussing this review, the questions raised are technical as well as outcomes-related. Seven technical questions were raised: (1) what is considered an adequate first decompressive surgery for Chiari malformation (i.e., amount of bone removed during suboccipital craniectomy and C1 laminectomy; (2) for patients with holocord syrinx with Chiari malformation, are they evaluated and ruled out for having a tethered cord prior to initial surgery; (3) when performing a duraplasty procedure, what other material besides pericranium is used in the literature and does it have an increased risk of recurrent/residual syrinx; (4) are cranioplasties being performed with tacking of the dural patch to allow for further increase/maintenance of the increased basal cistern space at the cervicomedullary junction; (5) are there comments made about basilar invagination or congenital skull base anomalies associated with this patient population; (6) is there any use of
9 Ellenbogen RG, Armonda RA, Shaw DW, Winn HR. Toward a rational treatment of Chiari I malformation and syringomyelia. Neurosurg Focus 2000;8(3):E6

10 Fischer EG. Posterior fossa decompression for Chiari I deformity, including resection of the cerebellar tonsils. Childs Nerv Syst 1995; 11(11):625-629

11 Garcìa-Uria J, Leunda G, Carrillo R, Bravo G. Syringomyelia: longterm results after posterior fossa decompression. J Neurosurg 1981;54(3):380-383

12 Mueller D, Oro' JJ. Prospective analysis of self-perceived quality of life before and after posterior fossa decompression in 112 patients with Chiari malformation with or without syringomyelia. Neurosurg Focus 2005;18(2):ECP2

13 Noudel R, Gomis P, Sotoares G, et al. Posterior fossa volume increase after surgery for Chiari malformation Type I: a quantitative assessment using magnetic resonance imaging and correlations with the treatment response. J Neurosurg 2011;115(3): 647-658

14 Silva JA, Melo LR, Araújo AF, Santos AA Jr. Resolution of syringomyelia in ten cases of "up-and-down Chiari malformation" after posterior fossa decompression. Arq Neuropsiquiatr 2010;68(5): 694-699

15 Vaquero J, Martínez R, Arias A. Syringomyelia-Chiari complex: magnetic resonance imaging and clinical evaluation of surgical treatment. J Neurosurg 1990;73(1):64-68

16 Zhang Y, Zhang N, Qiu H, et al. An efficacy analysis of posterior fossa decompression techniques in the treatment of Chiari malformation with associated syringomyelia. J Clin Neurosci 2011; 18(10):1346-1349

17 Heiss JD, Suffredini G, Smith R, et al. Pathophysiology of persistent syringomyelia after decompressive craniocervical surgery. Clinical article. J Neurosurg Spine 2010;13(6):729-742

18 Abla AA, Link T, Fusco D, Wilson DA, Sonntag VKH. Comparison of dural grafts in Chiari decompression surgery: Review of the literature. J Craniovertebral Junction Spine 2010;1(1):29-37

19 Sgouros S, Williams B. A critical appraisal of drainage in syringomyelia. J Neurosurg 1995;82(1):1-10

ultrasound intraoperatively to help "identify" adequate decompression with return of CSF circulation across the craniocervical junction; and (7) when treating the syrinx directly, do they prefer a syringopleural shunt in all cases, or do they utilize syringo-subarachnoid shunts, etc. as well? In the future, greater clarity on these variables can be expected to improve comparability of results. The technical question of verifying flow should be readily answerable with MR-based or ultrasonography flow studies. On the outcomes question, patient reported results in this population can be difficult to ascertain due to their frequently ambiguous subjective complaints concurrent with objective clinical findings. Though the literature is full of low-quality case review series with no uniform reporting measures on outcomes, it does give a place to start for further evaluation and expectations for patients with Chiari malformation and associated residual/recurrent syrinx. 